\title{
Differences Behind the Appearances: Export Growth, Technological Capabilities, and Development in Mexico and South Korea
}

\section{Raúl Delgado-Wise and Noela Invernizzi}

\begin{abstract}
In spite of the apparent parallel experiences followed by export growth in Mexico and South Korea, the authors argue that the two countries have followed radically contrasting economic and social development paths. The aim of this paper is to examine some of the strategic dimensions of the two paths in an attempt to demystify the aura of success created around the Mexican case.
\end{abstract}

RÉSUMÉ - La croissance des exportations a suivi des voies apparemment parallèles au Mexique et en Corée du Sud. Les auteurs soutiennent toutefois que le développement économique et social y a emprunté des voies radicalement différentes et opposées. Le but de leur article est d'examiner certaines dimensions stratégiques de ces deux voies pour tenter de démystifier l'aura de succès qui entoure le cas mexicain.

\section{INTRODUCTION}

At the onset of the $21^{\text {st }}$ century, Mexico has managed to position itself as the leading export power in Latin America and as seventh in the world, with an export platform comprising 84\% manufactured goods, of which $39 \%$ are classified as "high technology." Similarly, South Korea is among the most successful exporting economies of Southeast Asia, with an export platform that is $92 \%$ manufactured products, of which $32 \%$ are classified as "high technology." Both economies are further characterized by their high levels of openness (imports and exports as a percentage of GDP): $60 \%$ in the former, and $87 \%$ in the latter. Moreover, of the member countries of the Asia-Pacific Economic Cooperation agreement, Mexico and South Korea are among those that reported the highest annual rates of growth in their export volumes over the last decade (1990-2000): $16.1 \%$ and 10.2\% respectively.

Over and above the apparent parallel paths followed by export growth in Mexico and South Korea, it is undeniable that they have undergone radically different and contrasting economic and social development experiences. The aim of this paper is to examine some of the strategic dimensions of the two paths in an attempt to demystify the aura of success that certain sectors have tried to create around the Mexican case. Our main interest is to reveal the true nature of the country's export growth and to contrast it with the South Korean experience which, in a number of ways that we will attempt to illustrate, represents the antithesis of the neoliberal path chosen by Mexico.

At the heart of our argument is the hypothesis that one of the key elements in differentiating the two experiences lies in the nature, characteristics, and scope of the form of state interventionism 
followed, with South Korea adopting, in contrast to Mexico, a long-term approach with a deeply nationalistic view of the development process wherein scientific and technological development and education play a central role.

For the purpose of this analysis, the paper has been divided into four sections. The first highlights some basic features of the industrialization strategies followed in Mexico and South Korea prior to the 1980s. We then examine the contrasting forms adopted by export growth in the two nations in the context of neoliberal globalism. The third section illustrates the major differences in the training of human resources for learning and innovation in the two countries. Finally, the fourth section offers a critical comparison of the two experiences, with emphasis on their social implications.

\section{Two Alternative Paths Toward Late Industrialization}

Between the Second World War and the 1970s, Mexico, like other Latin American countries, followed a path of planned industrialization fostered by the state and based on the Economic Commission for Latin America and the Caribbean-inspired principle of "import substitution." With the support of a highly protectionist structure and major incentives for industrialization, encouragement was given toward the domestic production of goods that were previously imported, in the hope of progressively advancing domestic production from consumer goods to intermediate goods and, ultimately, capital goods.

With respect to this approach it should be noted that, first, even though it allows high rates of industrial growth $-6.4 \%$ per annum between 1940 and 1960 and $8.6 \%$ during the $1970 \mathrm{~s}$ - it generates increasing deficits in the balance of trade, compounded by startling levels of foreign debt.

Second, although industrialization favoured a sector of the national bourgeoisie, it also stated the conditions for the entry of foreign capital on a significant scale in the form of large transnational corporations.

Finally, far from creating an industrial base with the ability to compete on international markets, this industrialization path fostered inefficient industries with high levels of obsolescence and practically no capacity for innovation. All this leads to what Fajnzylber $(1985,150)$ characterizes as a process of truncated or precarious industrialization.

Disregarding certain similarities that some authors detect between the import substitution model followed by Mexico and the development model adopted by South Korea (López Villafañe 1999), the two countries clearly represent two alternative paths toward late industrialization, with significant contrasts in their theoretical basis, scope, and results. In fact, Estrada and Robles Báez (1995) suggested this when they comparatively analysed the economic and commercial reforms carried out by South Korea and Mexico over the 1980s.

Thus, as pointed out by Amsden (1989), in the 1960s South Korea began its industrialization process using an approach that emphasized learning. With that, it was able to achieve rates of annual growth even higher than those reported by Mexico: 9\% from 1962 to 1971 and 10\% from 1972 to 1979 , in conjunction with a moderate and decreasing deficit in the balance of trade.

Several institutions supported this path:

1. An interventionist and authoritarian state that decisively fostered the process of capitalist and industrial development with a long-term, nationalist outlook and that gave priority to education and training, together with a careful, selective, and intelligent protectionist policy and the gradual promotion of exports.

2. Chaebols, large family business groups created with strong state encouragement and support, which operate as executing agencies for industrialization plans and strategies (L. Kim 2000, 18). 
As Chibber (2004) suggested when comparing Indian and South Korean developmental states, the political elite of the latter was successful in harnessing domestic capitalists to their agenda. It should be noted that this process was accompanied by restrictions placed on direct foreign investment. In addition to encouraging technology transfers, this fostered an aggressive policy for the accumulation of technological capabilities and (unlike what happened in Mexico and other Latin American countries) prevented foreign multinational corporations from becoming the hegemonic agents of the accumulation process.

3. An expanding supply of executive-level human resources (managers) with a high proportion of engineers operating as the "guardians of technology transfers" (Amsden 1989, 9).

4. An unusually productive, qualified, and disciplined workforce to feed the industrialization process. This workforce was also subjected, particularly at the start of the process, to the longest working days in the world, in a context of authoritarianism and repression. At the same time, workers received certain productivity bonuses in the form of moderate wage increases. It is worth noting that average manufacturing wages in South Korea stood at US\$0.32 per hour in 1975 and, although they had risen to $\$ 0.96$ per hour in 1980 , they were still among the lowest in the world: one-seventh of prevailing wages in the United States and slightly less than half those found in Mexico. This cheap and productive workforce became a decisive factor, a sine qua non comparative advantage, in the success attained by the first phase of the South Korean industrialization process. Adelman $(1997,6)$ states that in addition to the long working days, during the first stage of Korea's industrialization there was a substantial increase in industrial accidents, indicating the intensified use to which the workforce was put.

One key aspect of this path is that it is underpinned by what L. Kim (2000) calls "imitative duplication." By means of reverse engineering, mature technology products and those that are labourintensive, such as textiles and toys, are copied and produced efficiently and effectively. As noted by Rosenberg $(2002,5)$, the activities of engineers and technicians were a determining factor, adding new knowledge to mature processes and technologies and thereby generating the advantages of efficiency needed to compete on the global market.

During the 1970s, the same strategy was applied to heavy industries, including automobiles, iron and steel, machine tools, and shipbuilding, and this enabled them to compete on the global market against consolidated producers. In addition, because of its defence and economic interests, the South Korean government encouraged the accelerated development of chemicals and heavy industry, and this was decisive both in the foreign technology assimilation process and in securing the competitiveness of other industries (L. Kim 2000, 19).

In addition to the different patterns of state intervention, the point to be emphasized with respect to the two alternative paths toward industrialization is that they are based on diametrically opposed ideas about the meaning and importance of technology and technological innovation in the development process (Delgado-Wise 1996). While in the import substitution model, technology is seen as just another commodity (always available for purchase and liable to be replaced at any time), in the industrialization through learning model it is considered a key strategic ingredient of the industrialization process. In the first case, the process is visualized statically as that which culminates with the substitution of capital goods without taking into consideration that at every step along the way innovation disrupts the entire structure established earlier. The situation is very different from the paradigm of industrialization through learning, where the goal is to construct "dynamic comparative advantages" (Amsdem 1989, 268). Indeed, late industrialization is a case of pure learning, a case in which, "for the first time in history, backwards countries industrialized without proprietary innovations" (2). 
Reference must be made to certain historical and geopolitical elements that are intimately tied with South Korea's industrialization process. The occupying Japanese forces, when they withdrew in 1945, left behind the rudiments of industry installed in the country. The Cold War then established a more than appropriate context by making the region a bulwark against the Communist advance and enabling it, on the one hand, to receive significant financial support from the United States and almost unrestricted access to that country's domestic market and, on the other, to establish a more balanced relationship with Japan vis-à-vis trade, investment, loans, and official development assistance. No less important was the Western support for a degree of social homogenization to prevent the dissemination of the Communist ideology, which took the form of agrarian reform, mass education campaigns, and the professionalization of the bureaucracy (López Villafañe 2002, 805; Dabat, Rivera, and Toledo 2001, 956). ${ }^{1}$ All this is in sharp contrast to the deeply asymmetrical relations established between Mexico and the United States.

\section{Contrasting Modes of Export Growth}

Under the aegis of the so-called neoliberal globalism, as noted above, both the Mexican and South Korean economies are characterized by the high level of dynamism in their manufactured exports, with "high technology" goods constituting a major component. The similarities in the export mixes of the two countries are shown in Figure 1.

The commonalities, however, stop there; investigating more deeply reveals that the export dynamism is not only based on very different industrialization strategies (substitution versus learning); it also reflects two radically contrasting forms of export growth.

To disentangle Mexico's experiences, sight must not be lost of the extremely rapid growth of the maquiladora export sector. Between 1982 (when the country's reorientation toward neoliberalism began) and 2004, this sector's foreign sales increased by a factor of 26, accounting in the final year for more than half of the entire manufactured export volume. Maquiladoras are intended to be assembly plants tied with internationalized productive processes and almost no integration with the domestic economy. They are thus characterized by importing most of the components they use and selling most of their output abroad (Dussel 2003; Dussel, Galindo, and Loría 2003) and by reducing their catalyzing impact to a meagre trickle of wage incomes. In addition, a process of "disguised maquila" has been seen emerging in other areas of export manufacturing, such as the automobile industry (Cypher 2004; Delgado-Wise 2004). ${ }^{2}$ Note that the total of temporary imports was equal to almost $80 \%$ of total exports over the past decade, between 1993 and 2000 (Dussel 2003).

This is compounded by the overwhelming preponderance of intra-firm trade with the United States, estimated to be between 65\% and 75\% (Arroyo 2003; Durán and Ventura-Dias, 2003; Baker 1995). In addition to contravening the "free market dynamics" preached by the neoliberal orthodoxy, this underscores the extreme plundering of the Mexican economy that is thus taking place. It

1. According to Adelman $(1997,6)$, unlike most developing countries, South Korea experienced redistribution before growth, thanks to its agrarian reforms in the 1950s and the universal coverage of basic education it achieved in the mid-1960s. Thus, during the first stages of growth, there was a relatively uniform distribution of wealth. However, this situation began to change in the 1980s.

2. Fujii $(2000,1014)$ noted this characteristic in the following terms: "The dynamism of the export sector does not pull the rest of the economy along with it; instead, it is filtered abroad, chiefly to the United States." Supporting this line of analysis, Cypher $(2001,12)$ holds that "Mexico's export 'miracle' can be largely explained by globalization strategies created in Detroit — the US auto industry accounted for approximately one out of every five dollars of Mexico's non-oil exports during 1997." 
should not be forgotten that the concept of shared production inherent in intra-firm trade does not mean shared profits. Export prices in commerce of this kind are set artificially by the companies without declaring "profits," which not only allows a net transfer of potential earnings abroad but also enables each job created to be subsidized and the bill for those subsidies to be passed on to the Mexican economy.

In addition to showcasing the fragility and volatility of the export dynamic, the foregoing comments require that we assess, in its true dimensions, the nature and scope of what the country actually exports. Thus, it is clear that the lion's share of Mexican foreign trade - that which makes up intra-firm trade and covers most of the maquiladora sector - is not accurately described as manufactured exports; as Carlos Tello $(1996,50)$ insightfully points out, what is being sold abroad is labour force, without it having to leave the country. Consequently, the veil of supposed progress in export manufacturing conceals the contraction of a part of the Mexican economy, which is reduced and compelled to serve as a supplier of cheap labour and a labour reserve for foreign capital, principally for American foreign capital.

Two additional comments serve to flesh out this point. First, in addition to its workforce (which is by far the country's chief export good, with a net contribution to the balance of trade in excess of US $\$ 35.7$ billion in 2004), ${ }^{3}$ Mexico exports natural resources (primarily oil) and assets. This latter element - the acquisition of assets at knock-down prices through the privatization of state-owned companies and from mergers with and acquisitions of domestic companies - has been targeted by a significant amount of direct foreign investment, underscoring not only the non-productive nature of this type of investment but also its acknowledged contribution to the processes whereby large multinational companies concentrate and centralize capital. It is worth adding that these investments have been channelled into acquiring the country's financial sector through the purchase of Mexico's largest banks: Bancomer, bought by Banco Bilbao Vizcaya, and Banamex, bought by Citibank (Villarreal 2004).

Second, the best illustration of the extremely restricted nature of the process of capital accumulation in Mexico is the ruthless transfer of surpluses that takes place in the neoliberal context under the hegemony of the United States. In this regard, John Saxe-Fernández and Omar Núñez (2001, 150-51) estimate that the total volume of surpluses transferred out of the country - chiefly to the United States — between 1982 and 1997 was, at constant 1990 prices, some US $\$ 457$ billion. ${ }^{4}$ The true dimensions of this figure, which does not include net transfers of profits through direct and indirect exports of labour, become apparent if we consider that Latin America is the underdeveloped world's leading tributary region and that, within that region, Mexico is the leading country.

It should also be noted that in such circumstances, the state's actions are considerably limited by the international financial agencies — the World Bank, International Monetary Fund, and the InterAmerican Development Bank (Petras and Veltmeyer 2001) — following the neoliberal prescription to the letter (liberalization, deregulation, and privatization) and abandoning all undertakings related to the development process. In turn, all this leads to an extreme process whereby the domestic market contracts and a good proportion of the domestic industrial base, constructed during the import substitution phase, is dismantled and destroyed (Katz 2001).

3. This estimate includes both the added value of the maquiladora sector as an approximate indicator of indirect labour exports, and the remittances sent home as a result of direct labour exports. See <http://www.banxico.org.mx>, accessed April 2004.

4. This figure mainly encompasses the external debt payments and transfers made through losses in the exchange rates of export products. 
South Korea's experience contrasts sharply with that of Mexico. Instead of breaking with the prior phase of industrialization, what occurred in the Korean case was the evolution from duplicative imitation to creative imitation. That means a qualitative step forward, apparent in the reorientation of its export mix toward technology-intensive products such as computers, semiconductors, VCRs, electronic systems, and high-definition televisions. This occurred against the backdrop of the socalled computer revolution and placed South Korea in a position to dispute privileged niches of the global market for key products in the new sphere of capital accumulation comprising the electronics and computer sectors (Dabat, Rivera, and Toledo 2001, 957). Thus, for example, the Korean corporation Samsung is currently the world's largest producer of memory chips; in recent years, South Korea has ranked first or second among the world's producers of cellular telephones, and it has secured a leading position in the development of wireless Internet services (Rosenberg 2002, 3).

Clearly, these achievements are based on a much more thorough development than that of Mexico of its technological capacity in pursuit of building the ability for independent innovation. According to L. Kim (2000), the encouragement given to the following five complementary strategic lines lies at the heart of this successful transition.

1. Transfers of advanced technology. In light of the increasing difficulty of securing sophisticated technology, it was decided to obtain them formally through licensing arrangements.

2. Reversing the brain drain. A successful policy to repatriate highly trained workers from abroad and put them to work in the research and development (R\&D) centres of Korean companies was pursued.

3. Major investment in $\mathrm{R} \& \mathrm{D}$, with growing private sector involvement (around $80 \%$ ). As essential cogs in the machinery of industrialization through creative imitation, companies begin to establish major research and development facilities with a view not only toward assimilating imported technology but also toward innovation and the creation of new knowledge. Note that in other countries that followed a late path to industrialization, such as Mexico and Brazil, practically no such advances were made.

4. Investment and changes in the university system. Low standards in the university system and its orientation toward teaching began to be addressed through investments and reforms in the 1980s (Lee 2000). In consideration of the difficulties inherent in making universities places for research, the government created a new agency, the Korea Advanced Institute of Science and Technology, to focus on science and engineering research.

5. Creation of several public research institutes. These institutes were directly geared toward the needs of industry and toward producing the experts needed by the companies' expanding research and development centres. Another aspect of this policy was the promotion of scientific cities, first with the construction of the failed Seoul Science Park and, later and more successfully, the Daeduck Science Town (L. Kim 1993, 380-81).

In recent years, South Korea has taken its first steps in the arena of innovation. In this incipient third phase of the process of late industrialization, Korea is placing itself as a producer at the cutting edge of technology in certain fields, such as semiconductors, and has even overtaken Japan. ${ }^{5}$ The competitive challenges are redoubled since as the country becomes a stronger competitor it encounters greater obstacles in securing foreign technology. In this context, in addition to the importance given to the public research institutes, the greater $\mathrm{R} \& \mathrm{D}$ efforts being made by companies, and the

5. Korea's shipbuilding industry has also managed to challenge Japan's dominant position (Dabat, Rivera, and Toledo $2001,955)$. 
corporate alliances for joint R\&D with foreign corporations, ${ }^{6}$ the government maintains that the function of the universities as the producers of new knowledge and of human resources for research is still of strategic importance.

In spite of the relative success of the South Korean experience, Suh $(2000,22)$ notes that the country is quite dependent on flows of foreign technology, the weight of which can be felt in its balance of payments. In addition, in the post-Cold War era, the geopolitical relationship between Korea and the United States is changing. The latter is increasingly interested in deregulating Korean and other late industrializing economies, and in breaking down their barriers to the broader globalist agenda that prefers corporations be headquartered in those countries (Pempel 2004, 4). However, the industrial development already achieved and the installed capacity for R\&D place Korea in an advantageous position to go on with its industrialization and technological development goals.

Over and above the regional and sectoral imbalances seen in the South Korean productive apparatus, which is excessively centralized around large corporations (chaebols), ${ }^{7}$ the country's progress toward creating a system of independent innovation should be emphasized.

It is clear that South Korea's export growth bears little resemblance to the neoliberal export growth of Mexico. While the former aims at evolving toward capitalist development, the latter implies a deepening of the country's underdevelopment. In turn, this is associated with their very different regional integration models (with their respective blocs) and patterns of participation on global markets. One case leads to greater dependence on and subordination to the imperialism of the United States, ${ }^{8}$ while the other represents an option for integration with a more open context of competition. Indicators on the apparent similarities between these processes can be seen in Table 1, while the following sections contain a series of indicators that showcase their contrasting results.

Table 1. Export Growth in Mexico and South Korea, 1990-2002

\begin{tabular}{lcccc}
\hline & \multicolumn{2}{c}{ Mexico } & \multicolumn{2}{c}{ South Korea } \\
& 1990 & 2002 & 1990 & 2002 \\
\hline Exports of goods and services (as \% GNP) & 19 & 27 & 30 & 39 \\
Percent of manufactured goods in total exports & 43 & 84 & 94 & 92 \\
Percent of high-tech goods in total exports & 8 & 21 & 18 & 32 \\
\hline
\end{tabular}

Source: UN HDI Report 2004

6. With the goal of constructing the knowledge base needed for positioning themselves as producers of new technology, many Korean companies have adopted the strategy of "globalizing" their research and development activities. This has been done by establishing R\&D centres in the United States, Japan, and various European countries through mergers with and acquisitions of foreign high-technology companies, and by entering into strategic alliances with leading multinational corporations (L. Kim 2000, 24). In 1996 Korea already had 32 R\&D centres in the United States, including 10 for semiconductors and seven for computers (Rosenberg 2002, 8).

7. Dabat, Rivera, and Toledo $(2001,955)$ note that Korea's industrial structure "has some extremely critical aspects, such as the exaggeratedly dominant position of the chaebols, which, because of their strategy and size, are highly biased toward super-production in very specialized sectors that demand enormous economies of scale."

8. "Neo-Monrovian" is what John Saxe-Fernández $(2001,171)$ calls the form of integration and subordination imposed on Latin America under the aegis of neoliberal globalization. 


\section{Human Resources For INNOVATION}

The apparent parallels between the two development models are weakened by an analysis of the process whereby human resources are trained in order to sustain learning and industrial innovation. The most remarkable feature is the rising curve followed by the education growth in South Korea since the 1950s, under the initial impulse of the reconstruction process that followed the end of the war (K.S. Kim 1999, 1). One salient feature of this growth is that, faced with a scarcity of resources and the decision to concentrate them on industry, encouragement was given toward the development of an education system wherein the private sector played a leading role. This, however, as occurred with industry, took place under the influence of a high degree of state intervention with respect to both economic factors (fees, etc.) and course contents (Adelman 1997, 4); as K.S. Kim $(1999,10)$ notes, this ultimately converted the de jure private universities and schools into de facto public institutions.

During the first half of the 1960s, the literacy rate rose from $30 \%$ to $80 \%$ with two-thirds of education costs covered by the private sector. In 1966, universal primary education was established, and Korea's level of tertiary education admissions surpassed that of the United Kingdom (Adelman 1997,5 ), thus satisfying the demand for labour required by the industrialization process in its phase of imitation or reverse engineering.

During the 1970s, the pressure to expand secondary education increased; it was consequently expanded, at a faster rate than had happened with primary schooling, until universal coverage was attained (see Table 2). This led to a surplus of qualified labour and unemployment; however, as noted by L. Kim (2000), the surplus served as a strategic reserve that was later absorbed as the country evolved from imitative industrialization to the creative phase. This latter phase relied on qualified workers at all levels, from the factory floor to the executive echelons now required to pursue innovations and the development of science and technology.

Table 2. Student Advancement through Schooling Levels in South Korea, 1970-1998

\begin{tabular}{lcccc}
\hline Student advancement though levels & 1970 & 1980 & 1990 & 1998 \\
Elementary to Initial Secondary Education* & 66.1 & 95.8 & 99.8 & 99.9 \\
Initial Secondary Education to High & & & & \\
$\quad$ Secondary Education* & 70.1 & 84.5 & 95.7 & 99.4 \\
High Secondary Education to College & 31.9 & 44.0 & 46.0 & 83.7 \\
\hline
\end{tabular}

Source: K.S. Kim $(1999,2)$

*Elementary Education: six years; Initial Secondary Education: three years; High Secondary Education: three years.

The 1990s saw the beginning of the harmonious development of the three levels of the Korean education system with an increasingly marked trend toward universal higher education. In 1998, 84\% of secondary-school graduates enrolled in tertiary education (K.S. Kim 1999, 2; L. Kim 2000, 18).

Although it must be admitted that pressure within the system - that is, the pressure brought to bear by one cycle of schooling on the subsequent level — played a major role in the accelerated development of the education system and that factors such as the incentives given to meritocratic competition (aspects stressed by K.S. Kim 1999) are behind the most recent expansion of the universities, it is also true that Korea's achievements in the field of education cannot be explained without acknowledging the ever-increasing demand for qualified workers created by the industrialization process and the development policies pursued by the Korean government. And while it is undeniable that the state's close control over the education apparatus served the ideological goals of the military 
government (Amsdem 1989), there is no question that it attained a high level of academic quality. One indicator of this is the performance of Korean pupils in the evaluations of science, mathematics, and reading and comprehension skills carried out in the secondary schools of 24 industrialized countries, in which South Korea has been ranked first among the OECD nations, followed by Japan (Asia Times 29 November 2002). ${ }^{9}$

The Mexican experience reports highly unequal growth in the different education levels, with universal coverage only in primary schooling. At the secondary level, enrollments cover $57 \%$ of young people in the corresponding age group, with only $19 \%$ at the tertiary level (UNESCO 2002). Figure 2 clearly shows how the gap between the two countries' education systems - as reflected in the proportion of people in school to the population as a whole - widened between 1970 and 2000.

It is obvious that Mexico's education system is incapable of providing as many qualified workers as South Korea's system. An historical analysis of the industrialization processes of the two countries reveals that a labour force such as Korea's was never demanded by the Mexican productive apparatus, which was, as seen above, notably inclined toward maquila assembly work. ${ }^{10}$

In contrast to Korea's experiences, Mexico's industrialization bears little or no relationship to processes of learning or innovation. That is the reason why, while Mexico has 214 scientists and engineers engaged in R\&D for every million inhabitants, South Korea has 2193 (OECD 2001); this fact serves only to illustrate, with crystal clarity, the role played by higher education in Korea's industrial development where, on the one hand, universities act as the generators of trained experts for fuelling that process and, on the other, industry tends to absorb them into its R\&D activities. Thus, while South Korea spends $2.46 \%$ of its GDP on R\&D - a level close to that of the United States, which invests $2.64 \%$ of GDP in R\&D — Mexico spends a paltry $0.43 \%$ (1999 figures). Unlike many countries, particularly newly industrialized ones, spending on R\&D in Korea is mostly private ( $73 \%$ of the total).

It is important to underline that such passive behaviour of the Mexican private sector regarding R\&D investment is clearly related, on one hand, to the high presence of multinational companies, which perform their R\&D activities abroad and, on the other hand, to the maquila character of most Mexican export industry, which is mainly the assembly of imported parts.

\section{Export Growth and Social Development}

Although the two countries have reported similar export growth curves, the implications of that growth in terms of social development are clearly different. This can be seen in indicators such as per capita GDP, the human development index, the Gini index, and workers' wage levels.

In 2000, Mexico's per capita GDP stood at US\$9023, while South Korea's was $\$ 17,380$. In addition, the human development indices (HDI) for the two nations placed them at 27th and 51st, respectively (UN 2002 HDI Report). There has been a pronounced widening of the gap between the two during the past quarter century: in 1975, the two countries' HDIs were similar, at 0.688 and 0.687 , while in 2000 they had changed to 0.796 and 0.882 .

9. These evaluations are performed by UNICEF and involve two tests: Program for International Student Assessment (PISA), and Trends in International Math and Science Study (TIMSS).

10. It is still worth noting that in recent years, due to management innovations related to quality control, there is a tendency toward demanding — albeit at levels comparatively more limited than Korean standards — higher levels of schooling among the country's workforce. 
Similarly contrasting are the levels of social inequality that exist in the two countries. The counterpoint to the disfigured face shown by the Mexican economy under the scaffolding of export growth — within which it clearly resembles an "enclave"ll (Delgado-Wise and Mañán 2000) — is provided, on the one hand, by the growing disarticulation, contraction, and dismantling of the domestic sphere of accumulation and, on the other, by the impoverishment of most of the population, the accentuation of social inequalities, and the creation of a burgeoning mass of workers who are unable to find employment within the country's formal job market. Note that Mexico is "the country with the fastest growth in the number of multi-millionaires and in the number of people in conditions of poverty in the world" (González Casanova 2001, 127). In just one decade — from the mid-1980s to the mid-1990s — its Gini coefficient rose from 49 to 55 (Oxfam 2002, 136), leading to a mass of poor people who, according to officially sanctioned figures, total 53.7 million (SEDESO 2002).

In contrast to Mexico, South Korea reported a Gini coefficient of 30.8 in 1989, which fell to 28 in 1993 and remained in that general area, with minor ups and down, until the 1997 crisis. It then rose to 32 in 1999 (Korea Labour \& Society Institute 2001). Although Korea has developed successful policies for eliminating absolute poverty, some authors are critical of the country's capacity to reduce inequality at the same rate as economic growth. They argue that while the early phases of industrialization entailed more equal growth, since the 1980s there have been greater inequalities, regardless of the significant increase in average incomes and other standard-of-living indicators (Adelman 1997, 12; Chiang 2001, 6). Even so, it remains true that the levels of inequality recorded in Mexico are substantially higher than Korea's, and that they are growing at a faster rate.

Finally, there are also considerable disparities in the wages earned by the workers on whom the two countries' export growth is based. According to data from the U.S. Department of Labor, whereas manufacturing wages in Mexico remained practically unchanged between 1980 and 1999 (some slight variations did occur), falling from US $\$ 2.21$ to $\$ 2.12$ per hour, over the same period the South Korean figure rose from $\$ 0.96$ to $\$ 6.71$. Moreover, by 2001 it had risen to $\$ 7.77$ per hour, making South Korea the country with the highest manufacturing wages among the newly industrialized nations of Southeast Asia. This differential between earnings in the two countries must be seen in relative terms in that there are differences in the costs of living in each. Thus, for example, Chiang $(2001,12)$ shows that the high price of land in South Korea erodes the purchasing power of wages. ${ }^{12}$ It should be noted that wage levels also depend on the unequal capacity for organization of the two working classes. But this sizeable gap also reveals the reproduction cost of workers with very different productivity standards, an issue wherein training time is of different length in each of the countries.

The democratization of South Korea changed the situation of its workers, affecting labour costs. Now unionized and less "submissive" than in more repressive times, Koreans no longer work as hard as they used to in decades past. Wages have been increasing constantly although, at the same time, temporary and per-day employment arrangements are becoming more common (Korea Labour \&

11. Strictly, it should be noted that we are not using the concept of "enclave" as it is traditionally accepted. We are using the term to refer to the plundering and expropriation of a portion (and not necessarily a small one) of the nation's territory by foreign capital by means of a construct that brandishes highly destructive "macroeconomic conditions" that restrict the domestic economy.

12. The author shows that while the relationship between real wages and consumer goods prices displayed continuous growth between 1974 and 1989 (the result of a threefold increase in purchasing power for consumer goods), the purchasing power of wages with respect to property prices remained constant (Chiang 2001, 11). 
Society Institute 2001). With the production of technology-intensive goods, the comparative advantages associated with cheap, qualified labour have been relegated to the past (Suh 2000; L. Kim 2000).

Table 3. Mexico and South Korea: Contrasting Social Development Indicators

\begin{tabular}{lcc}
\hline & Mexico & South Korea \\
\hline Gini coefficient (Mexico, year 2000; Korea, year 1998) & 54.6 & 31.6 \\
Per capita GNP in 2002 (PPP US\$) & 8970 & 16,950 \\
Combined gross enrollment ratio for primary, secondary, and & & 92 \\
tertiary schools (\%) 2001-02 & 74 & 6.71 \\
Manufacturing wage per hour in 1999 (US\$) & 2.12 & 28 \\
Relative Position in UN Human Development Indicators Index in 2004 & 53 & 0.888 \\
UN Human Development Index in 2002 & 0.802 & \\
\hline
\end{tabular}

Source: Korea Labour \& Society Institute 2001; UN HDI Report 2004

\section{Conclusion}

Through a comparative analysis of the export growth processes of Mexico and South Korea, we sought to demonstrate that behind the apparent similarities in the two countries' export sector performance were fundamental differences in the forms of development implemented and in their impact on the social development of the two nations. On the one hand are the pronounced asymmetries and inequalities in the construction of their respective scientific and technological capabilities. This helps explain why, their apparently similar performances notwithstanding, there is such a large gap in terms of technological progress with, according to the UN classification, Mexico and South Korea ranking $32^{\text {nd }}$ and $5^{\text {th }}$, respectively (UN Human Development Report 2002).

On the other hand, the two countries' social indicators confirm that two strongly divergent development styles were adopted. The nationalist nature of Korea's development has had a greater impact on social development than Mexico's foreign-oriented and clearly neoliberal-inspired export growth.

The comparison of the Mexican and Korean cases does not presume to offer "recipes" for development, which, as we know, are difficult to transfer from one context to another. However, it is important for underscoring the fact that the planned and systematic construction of such a technological capability is impossible without active participation by the state. State intervention in South Korea was crucial for successful industrial development and for the scientific, technological, and educational policies that supported industrialization. The Korean late industrialization process is, in many ways, the antithesis of the neoliberal path experienced in Mexico as well as in other Latin American countries, a path strongly supported by international agencies and that is leading to increased inequality and underdevelopment.

\section{REFERENCES}

Adelman, I. (1997) “Social Development in Korea, 1953-1993,” available on-line: <http://are.berkeley.edu/ adelman/KOREA.html> accessed 27 November 2002.

Amsden, A.H. (1989) Asia's Next Giant: South Korea and Late Industrialization, New York: Oxford University Press.

Arroyo, A. (2003) "Promesas y realidades: el Tratado de Libre Comercio de América del Norte en su noveno año," Revista venezolana de economía y ciencias sociales, 9:2.

Asia Times (2002) "Education: Korea and Japan have the advantage," available on-line: <http://www.atimes. com> accessed 29 November 2002. 
Baker, G. (1995) “Sector externo y recuperación económica en México,” Comercio Exterior 45:5, 398-408.

Chiang, B. (2001) "Why Has Korea Defied the Kuznets Hipótesis? A Case Study of the Income Inequality Situation in Korea with Implications for Canada," available on-line: $<$ http://www.bicd.net/writing/kii.htm $>$ accessed 3 December 2002.

Chibber, V. (2004) Locked in Place: State-Building and Late Industrialization in India, Princeton, NJ: Princeton University Press.

Cypher, J.M. (2004) "Development Diverted: Socioeconomic Characteristic and Impacts of Mature Maquilization," in K. Kopinak (ed.) The Social Cost of Industrial Growth in Northern Mexico, San Diego: University of California.

_. (2001) “Developing Disarticulation Within the Mexican Economy," Latin American Perspectives 28:3, $11-37$.

Dabat, A., M.A. Rivera, and A. Toledo (2001) "Revaluación de la crisis asiática: espacio, ciclo y patrón de desarrollo regional," Comercio Exterior 51:11, 951-69.

Delgado-Wise, Raúl (2004) “Critical Dimensions of Mexico-US Migration under the Aegis of Neoliberalism and NAFTA," Canadian Journal of Development Studies 25:4, 591-605.

—. (1996) "Progreso tecnológico y capital monopolista," Investigación Económica 216, 85-101.

Delgado-Wise, Raúl and O. Mañán (2000) “México: the Dialectics of Export Growth,” Working Papers in International Development 00.10.2, Saint Mary’s University, Halifax, Canada.

Durán, J. and V. Ventura-Dias (2003) Comercio intrafirma: concepto, alcance y magnitud, Santiago: Cepal.

Dussel, E. (2003) “Ser o no ser maquila, ¿es ésa la pregunta?” Comercio Exterior 53:4.

Dussel, E., L. Galindo, and E. Loría (2003) Condiciones y efectos de la Inversión Extranjera Directa y del proceso de integración regional en México durante los años noventa: Una perspectiva macroeconómica, Buenos Aires: BID.

Estrada López, J.L. and M.L. Robles-Báez (1995) "Un análisis comparativo de las reformas comerciales y la competitividad industrial en Corea y México durante da década de los ochenta," Economía: Teoría y Práctica $4,63-72$.

Fajnzylber, F. (1985) La Industrialización Trunca de América Latina, Mexico: Nueva Imagen.

Fujii, G. (2000) "El comercio exterior manufacturero y los límites al crecimiento económico de México," Comercio Exterior 50:11, 954-67.

González Casanova, P. (2001) La universidad necesaria en el siglo XXI, Mexico: Era.

Katz, J. (2001) "Cambios en la estructura y comportamiento del aparato productivo latinoamericano en los años 1990: Después del Consenso de Washington, ¿qué?” in G. Dutrénit et al. (eds.) Sistema Nacional de Innovación. Temas para el Debate en México, México: Universidad Autónoma Metropolitana, 45-84.

Kim, K.S. (1999) “A Statist Political Economy and High Demand for Education in South Korea," Education Policy Analysis Archives 7:19, available on-line: $<$ http://olam.ed.asu.edu/epaa/v7n19.html $>$ accessed 3 December 2002.

Kim, L. (2000) “The dynamics of technological learning in industrialization,” INTECH-UNU Discussion Paper Series \#2000-7, Maastricht, The Netherlands.

_- (1993) "National System of Industrial Innovation: Dynamics of Capability Building in Korea," in R. Nelson (ed.) National Innovation Systems. A Comparative Analysis, New York: Oxford University Press.

Korea Labour \& Society Institute (2001), available on-line: <http://www.klsi.org/english/new/default.asp > accessed 17 November 2001.

Lee, J.K. (2000) “Main Reform on Higher Education Systems in Korea," Revista electrónica de investigación educativa 2:2, 1-16, available on-line: <http://redie.ens.uabc.mx> accessed 15 November 2002.

López Villafañe, V. (2002) “El desarrollo de Asia Pacífico al inicio del siglo XXI,” Comercio Exterior 52:9, 802-07.

. (1999) Asia en Transición: Auge, crisis y desafíos, Mexico: Siglo XXI.

OECD (2001) "World Development Indicators 2001," available on-line: <http://www.oecd.org> accessed 1 November 2002.

Oxfam (2002) “Rigged Rules and Double Standards: Trade, globalisation, and the fight against poverty," available on-line: <http://www.maketradefair.com> accessed 26 October 2002. 
Pempel, J.J. (2004) “Undone by success?” Issues \& Studies 40:1, 73-80.

Petras, J. and H. Veltmeyer (2001) Globalization Unmasked. Imperialism in the 21st Century, Canada: Zed Books/Fernwood Publishing Company.

Rosenberg, N. (2002) “Sources of Innovation in Developing Economies: Reflections on the Asian Experience," Amilcar Herrera Lecture at the Institute for New Technologies, Maastricht, The Netherlands, 26 September 2002.

Saxe-Fernández, J. (2001) “América Latina-Estados Unidos en la posguerra fría," in J. Saxe-Fernández and J. Petras (eds.) Globalización, Imperialismo y Clase Social, Buenos Aires: Lumen.

Saxe-Fernández, J. and O. Núñez (2001) "Globalización e Imperialismo: la transferencia de excedentes de América Latina,” in J. Saxe-Fernández and J. Petras (eds.) Globalización, Imperialismo y Clase Social, Buenos Aires: Lumen.

SEDESO (2002), available on-line: <http://www.sedesol.gob.mx/index/main.htm> accessed November 2002.

Suh, J. (2000) “Korea's Innovation System: challenges and new policy agenda," INTECH-UNU Discussion Paper Series \#2000-4. Maastricht, The Netherlands.

Tello, C. (1996) “La economía mexicana: Hacia el tercer milenio,” Nexos 223, 47-55.

United Nations (2004) “Human Development Report 2004,” available on-line: <http://hdr.undp.org/reports/ global/2004> accessed 1 July 2004.

. (2002) “Human Development Report 2002," available on-line: <http://www.undp.org/hdr2002> accessed 3 January 2003.

UNESCO (2002) Institute for Statistics, available on-line: <http://www.uis.unesco.org/ev_en.php?ID=2867_ 201\&ID2=DO_TOPIC $>$ accessed October 2002.

Villarreal, R. (2004) TLCAN; 10 años después: Experiencia de México y lecciones para América Latina, Bogotá: Norma. 